\title{
IMPLANTASI VITAMIN E UNTUK MEMACU PEMATANGAN GONAD INDUK IKAN BANDENG (Chanos chanos Forskal)
}

\author{
Agus Prijono*), Ketut Sugama*), Zafril Imran Azwar"), \\ Toni Setiadharma*) dan Tatam Sutarmat*
}

\begin{abstract}
ABSTRAK
Vitamin $\mathrm{E}$ adalah salah satu jenis vitamin yang digunakan untuk mempercepat pematangan gonad ikan. Penelitian ini bertujuan untuk mengetahui dosis implantasi vitamin E yang efektif dalam memacu pematangan gonad induk bandeng. Induk ikan bandeng dengan bobot rata-rata 4,62 $\pm 0,99 \mathrm{~kg}$ sebanyak 56 ekor dipelihara dalam 7 buah bak beton volume $20 \mathrm{~m}^{3}$ masing-masing berisi 8 ekor induk dengan pergantian air 500\%/hari. Vitamin E dalam bentuk kristal diformulasikan dalam kolesterol dan dicetak bentuk pelet. Tiga perlakuan dosis pelet vitamin E, yakni 50;100,;150 $\mu \mathrm{g}$ dan kontrol (tanpa vitamin E) diimplantasikan setiap bulan selama 6 bulan. Hasil penelitian menunjukkan bahwa implan vitamin $\mathrm{E}$ bentuk pelet dosis $100 \mu \mathrm{g}$ lebih efektif dari pada dosis 50 dan $150 \mu \mathrm{g}$ maupun dengan kontrol. Induk dengan perlakuan implan vitamin $\mathrm{E} 100 \mu \mathrm{g}$ memijah sebanyak 5 kali dan menghasilkan telur sejumlah 1.908 .000 butir dengan tingkat pembuahan dan penetasan, masing-masing $94,69 \%$ dan $97,0 \%$.
\end{abstract}

\section{ABSTRACT: Implant of vitamine e for gonad maturation of milkfish spawners (Chanos chanos Forsskal). By: Agus Priyono, Ketut Sugama, Z.I Azwar, Toni Setiadharma and Tatam Sutarmat.}

Vitamine $E$ is considered important in inducing gonadal maturity of fish. The purpose of the experiment was to find out of the effective dosage of vitamin $E$ for maturation and spawning of milkfish. Fifty six broodstock of $4.62 \mathrm{~kg}( \pm 0.99)$ were placed into seven $20 \mathrm{~m}^{3}$ concrete tanks. Each tank was filled with 8 fishes with water exchanged of $500 \%$ per day. Crystal of vitamin $E$ formulated in cholesterol pellet type package was used. Three treatments of vitamine $E$ implanted pellet were used i.e: 50; 100; $150 \mu \mathrm{g}$ and a control (placebo). Implanting of broodstock was conducted every month during six months of experiment. The result showed that the dosage of 100 $\mu \mathrm{g}$ pelleted vitamin $E$ was more effective for gonad maturation compared to the implanted dosage of 50 and $150 \mu \mathrm{g}$. The broodstock implanted with vitamine $E$ at $100 \mu \mathrm{g}$ spawned 5 times and produced 1.908 .000 eggs with fertilization and hatching rates of $94.69 \%$ and $97 \%$, respectively.

KEYWORDS: Gonad maturation, milkfish, vitamine E, implantation.

\section{PENDAHULUAN}

Induk ikan bandeng, Chanos chanos Forsskal dapat dipercepat pematangan gonad maupun pemijahannya dengan cara buatan, yaitu penyuntikan HCG cair, kristal hormon LHRH-a atau $17 \alpha$-metyltestosterone dan $\mathrm{CPH}$ kristal dengan variasi dosis yang umum digunakan (Lee et al., 1986; Crim, 1985; Marte et al., 1985; Prijono et al., 1990). Penggunaan hormon dalam proses reproduksi tersebut sangat berpengaruh dalam meningkatkan frekuensi pemijahan dan produksi telur yang berkesinambungan. Karena proses stimulasi hormonal yang berlebihan, dikhawatirkan terjadi penurunan kemampuan gonad dalam membentuk sel telur karena tidak diimbangi dengan nutrisi yang baik untuk menjaga kualitas sel telur yang ada. Upaya mempercepat masuknya unsur nutrisi dalam sel memerlukan peningkatan fungsi permeabilitas membran sel dengan menggunakan vitamin E. Pemanfaatan vitamin $\mathrm{E}$ ( $\alpha$-tocopherol) untuk beberapa spesies hewan maupun ikan tampaknya dapat menjamin adanya proses reproduksi yang sempurna. Vitamin E sebagai antioksidan sangat berguna untuk mengawetkan vitamin-vitamin dan asam lemak

\footnotetext{
*) Peneliti pada Loka Penelitian Perikanan Pantai Gondol, Bali
} 
tak jenuh yang mudah teroksidasi, baik yang terdapat dalam makanan, campuran bahan makanan maupun dalam tubuh. Karena pentingnya vitamin $\mathrm{E}$ untuk reproduksi ikan banyak peneliti yang telah mencoba pada beberapa jenis ikan antara lain ikan mas (Watanabe et al., 1977), ikan rainbow trout (Pozo et al., 1988; Cowey et al., 1983) dan red sea bream (Watanabe et al., 1984).

Pada umumnya konsentrasi vitamin E yang tinggi terdapat pada sel telur dan konsentrasi yang rendah terdapat pada lapisan jaringan gonad sesaat setelah induk memijah. Dengan demikian diduga bahwa vitamin $\mathrm{E}$ banyak mempengaruhi fungsi fisiologis pada pemijahan, fertilitas maupun penetasan telur yang dihasilkan (Watanabe, 1985). Vitamin E yang digunakan untuk membantu proses reproduksi umumnya diberikan dalam pakan dengan konsentrasi berbeda berdasarkan jenis maupun umur ikan, sehingga dikhawatirkan fungsi vitamin $\mathrm{E}$ tidak berjalan secara normal dalam pembentukan sel organ reproduksi. Untuk mengetahui efektivitas vitamin $\mathrm{E}$ dalam mendukung reproduksi perlu dilakukan penelitian implantasi vitamin E dalam bentuk pelet pada induk ikan bandeng.

\section{BAHAN DAN METODE}

Percobaan dilaksanakan di Loka Penelitian Perikanan Pantai Gondol. Induk ikan bandeng yang digunakan untuk percobaan berjumlah 56 ekor dengan bobot rata-rata 4,62 $\pm 0,99 \mathrm{~kg}$ per ekor yang dibagi dalam 7 bak beton berkapasitas $20 \mathrm{~m}^{3}$. Selama pemeliharaan dilakukan pergantian air laut sebanyak $500 \%$ per hari melalui sistem air mengalir dan pemberian aerasi secara kontinyu. Induk-induk tersebut diberi pakan berupa pelet yang merupakan campuran pakan komersial dengan filtrat ikan lemuru dengan perbandingan $1: 1$, sebanyak $2-3 \%$ bobot tubuh tiap hari. Komposisi kandungan pelet terdiri atas protein $37 \%$, lemak $12 \%$ dan serat kasar $2 \%$, sedangkan penyimpanannya dalam kamar dengan suhu $\pm 20^{\circ} \mathrm{C}$.

Perlakuan yang diterapkan adalah pemberian vitamin $\mathrm{E}$ (bentuk serbuk) yang diformulasikan dalam bentuk pelet dengan dosis berbeda, yaitu $50,100,150 \mu \mathrm{g}$ dan kontrol (tanpa pemberian vitamin $\mathrm{E}$ ). Induk bandeng diimplan secara individu setiap bulan bertepatan dengan pengamatan perkembangan gonad dan pengambilan contoh darah. Metode memformulasikan pelet vitamin E adalah dengan mencampur kolesterol sebanyak $190 \mathrm{mg}$ secara merata dengan vitamin E sesuai dosis yang ditentukan, dan ditambahkan dengan 1 tetes cocobutter, diaduk secara homogen dan selanjutnya dicetak dalam bentuk pelet berdiameter $\pm 300 \mu \mathrm{m}$ dan panjang $\pm 500 \mu \mathrm{m}$, yang dikemas menjadi tujuh butir pelet. Implantasi dilakukan dengan membuang satu sisik di bawah sisik punggung ikan uji dengan skalpel, kemudian diimplankan satu pelet vitamin $\mathrm{E}$ sesuai dosis perlakuan.

Pengamatan perkembangan sel telur dan sperma dilakukan setiap bulan dengan sistem kanulasi, yaitu memasukkan kanula pada lubang pelepasan sedalam $\pm 30 \mathrm{~cm}$ dan dilakukan penyedotan. Perkembangan gonad induk didasarkan pada ukuran diameter telur dan jumlah relatif sperma mengikuti metode dari Prijono et al. (1993), dengan parameter Neg: Negatip, PV: Previtellogenesis (diameter telur 150-250 $\mu \mathrm{m}$ ), SV: Small Vitellogenesis (diameter telur 250-400 $\mu \mathrm{m}), \mathrm{MV}$ : Medium Vitellogenesis (diameter telur 400-600 $\mu \mathrm{m}$ ), LV: Large Vitellogenesis (diameter telur $600-750 \mu \mathrm{m}),+1 ;+2$; dan +3 : banyaknya sperma.

Pengamatan vitamin E dan total kolesterol yang terkandung dalam darah dilakukan dengan cara mengambil contoh darah sebanyak $2 \mathrm{~mL}$ dengan jarum suntik $5 \mathrm{~mL}$ pada bagian pangkal ekor induk ikan yang diberi tanda. Darah yang terambil disimpan dalam kotak yang diberi es, kemudian dibawa ke laboratorium untuk analisis lebih lanjut. Contoh darah dipusingkan dengan kecepatan 600-1000 rpm selama 10 menit. Serum yang diperoleh diambil dengan jarum suntik 1 $\mathrm{mL}$ dan dipindahkan pada tabung reaksi volume $5 \mathrm{~mL}$. Serum yang diperoleh disimpan dalam alat pembeku dengan suhu $-30^{\circ} \mathrm{C}$. Vitamin E dalam serum selanjutnya dianalisis menggunakan HPLC (High Performance Liquid Chromatograph).

Preparasi untuk analisis vitamin E dalam serum adalah dengan memipet $100 \mu \mathrm{L}$ serum ke dalam tabung $5 \mathrm{~mL}$ dan ditambahkan $200 \mu \mathrm{L}$ heksan. Selanjutnya campuran tersebut dikocok dengan vortex mixer selama 45 detik, dan dipusingkan pada kecepatan $2200 \mathrm{rpm}$ selama 5 menit. Kemudian lapisan atas diambil $100 \mu \mathrm{L}$ dan dipindahkan pada tabung bervolume 3-5 mL. Ke dalam tabung tersebut dialirkan nitrogen, sehingga heksan menguap, sedangkan larutan ter- 
tinggal. Bila heksan sudah menguap sempurna, ditambahkan $100 \mu \mathrm{L}$ campuran dikhlorometan dan ethanol dengan perbandingan 1:3, kemudian cairan diambil sebanyak $10 \mu \mathrm{L}$ untuk dianalisis dengan metode Bieri et al. (1979).

Alat yang digunakan untuk menganalisis kandungan vitamin $\mathrm{E}$ dalam serum adalah HPLC terdiri atas injektor model U6K, pompa model 510 dan detektor Lambda Max Model 481, yang dioperasikan dengan laju aliran $2 \mathrm{~mL} /$ menit dan pada panjang gelombang 280. Kolom yang dipakai adalah BODANPACK C18 dengan diameter partikel $10 \mu \mathrm{m}$. Panjang kolom $25 \mathrm{~cm}$ diameter $0,4 \mathrm{~cm}$. Fase mobil campuran methanol dan air adalah 95:5.

Analisis total kolesterol serum dilakukan dengan spesial Kit dari MENARINI Italia. Prosedur analisis total kolesterol menggunakan sistem penguraian kolesterol esterifikasi secara enzimatik ke bentuk kolesterol bebas. Dua $\mathrm{mL}$ serum ditambah larutan penyangga dan enzim, diinkubasikan pada suhu kamar selama 10 menit, kemudian diukur dengan spektrofotometer dengan panjang gelombang 500 .

Pengamatan kualitas larva yang dihasilkan didasarkan pada rumus Mushiake dan Sekiya (1993):

Survival activity index $(\mathrm{S} \mathrm{A} \mathrm{I})=1 / \mathrm{N} \Sigma(\mathrm{N}-\mathrm{hi}) \mathrm{x}$ i

Keterangan:

$\mathrm{N}=$ jumlah larva yang digunakan untuk pengamatan

hi $=$ jumlah larva mati saat pengamatan

I = waktu yang dibutuhkan untuk pengamatan

Pemantauan kualitas air pemeliharaan induk dilakukan 1 kali dalam seminggu yang meliputi suhu, salinitas, oksigen terlarut, nitrit, nitrat. $\mathrm{pH}$ dan fosfat.

\section{HASIL DAN PEMBAHASAN}

Hasil pengamatan perkembangan sel telur dan sperma induk ikan setiap bulan dari Agustus 1995 sampai Februari 1996 dapat dilihat pada Tabel 1. Pada perlakuan tanpa pemberian vitamin $\mathrm{E}$ (kontrol) induk bandeng tidak mem perlihatkan perkembangan gonad, terbukti dari hasil pemantauan kanulasi individu pada bulan September sampai Desember. Walaupun demikian pada bulan Desember diperoleh perkem- bangan awal sel telur (previtelogenesis). Gonad induk bandeng tanpa pemberian vitamin $\mathrm{E}$ nampaknya tidak dapat berkembang dengan baik. Hal tersebut kemungkinan dipengaruhi oleh beberapa faktor terutama umur, lingkungan, pakan, vitamin, serta pengaruh hormonal alami yang mampu meningkatkan aktivitas reproduksinya. Perlakuan implan vitamin E dengan dosis 50 $\mu \mathrm{g}$, ternyata menghasilkan perkembangan sel telur dari tingkat previtellogenesis sampai small vitellogenesis pada bulan September dan Oktober. Sementara itu dengan cara pengurutan pada bulan Nopember terjadi perkembangan sperma pejantan tingkat positip 2. Pemantauan perkembangan gonad ikan yang diimplan dengan dosis vitamin E $50 \mu \mathrm{g}$ sampai bulan Februari belum memperlihatkan induk bertelur. Pemberian vitamin $\mathrm{E}$ dosis $50 \mu \mathrm{g}$ mungkin diperkirakan terlalu rendah sehingga dapat menyebabkan kerusakan atau kegagalan fungsi sel membran pembentuk jaringan telur. Hal tersebut sesuai dengan pendapat Halver (1985) bahwa rendahnya vitamin E yang diberikan akan mengakibatkan fungsi membran sel menurun. Demikian pula pendapat Watanabe (1985) yang telah memberikan vitamin $\mathrm{E}$ yang dosis rendah pada ikan Ayu (Plecoglossus altivelis) dan dihasilkan sepertiga dari jumlah induk betina tidak memijah.

Hasil pengamatan perkembangan gonad induk yang mendapat implan vitamin $\mathrm{E}$ dosis $100 \mu \mathrm{g}$ pada awal implantasi, tampak gonad berkembang sampai previtellogenesis. Pada bulan berikutnya perkembangan gonad sampai small vitellogenesis, hingga bulan Oktober saat mana gonad induk berkembang lebih banyak dan meningkat sampai medium vitellogenesis pada induk betina dan pada tingkat positip 2 dan 3 pada yang jantan (Tabel 1).

Hasil pengamatan implan vitamin $\mathrm{E}$ dosis 150 $\mu \mathrm{g}$ terhadap perkembangan sel telur maupun sperma diketahui mulai berkembang satu bulan setelah implantasi yaitu betina dengan 2 ekor previtellogenesis dan 2 ekor small vitellogenesis dan yang jantan pada tingkat positip 1 (1 ekor) dan positip 2 (2 ekor). Dan bulan kedua (Oktober) diketahui sel telur berkembang lebih besar dari previtellogenesis hingga large vitellogenesis dan yang jantan diketahui pada tingkat positip 2 . Terbukti pada induk betina gonad diketahui dapat berkembang dari medium vitellogenesis hingga large vitellogenesis dan jantan dari positip 1 hingga positip 3 , pada hal kecepatan produksi 
Priojono, A.; Sugama, K.; Azwar, Z.I.; Setidharma, T. dan Sutarmat, T.

Tabel 1. Pengamatan perkembangan gonad yang diimplan dengan pelet vitamin E.

Table 1. Observation on gonad development of milkfish broodstock implanted by pelleted vitamin E.

\begin{tabular}{|c|c|c|c|c|c|c|c|c|c|}
\hline \multirow{2}{*}{$\begin{array}{l}\text { Dosis } \\
\text { Dosage } \\
(\mu \mathrm{g})\end{array}$} & \multirow{2}{*}{$\begin{array}{c}\text { Sampel } \\
\text { gonad } \\
\text { Gonad } \\
\text { sample } \\
\end{array}$} & \multicolumn{7}{|c|}{ Bulan (Month) } & \multirow{2}{*}{$\begin{array}{c}\text { Keterangan } \\
\text { Remark }\end{array}$} \\
\hline & & $\begin{array}{l}\text { Agst. } \\
\text { Aug. }\end{array}$ & $\begin{array}{l}\text { Sept. } \\
\text { Sept. }\end{array}$ & $\begin{array}{l}\text { Okt. } \\
\text { Oct. }\end{array}$ & $\begin{array}{l}\text { Nop. } \\
\text { Nov. }\end{array}$ & $\begin{array}{l}\text { Des. } \\
\text { Dec. }\end{array}$ & $\begin{array}{l}\text { Jan. } \\
\text { Jan. }\end{array}$ & $\begin{array}{l}\text { Feb. } \\
\text { Feb. }\end{array}$ & \\
\hline 50 & $\begin{array}{c}\text { Neg } \\
\text { PV } \\
\text { SV } \\
\text { MV } \\
\text { LV } \\
+1 \\
+2 \\
\end{array}$ & 16 & $\begin{array}{c}14 \\
1 \\
1\end{array}$ & $\begin{array}{c}14 \\
1\end{array}$ & $\begin{array}{l}7 \\
9\end{array}$ & $\begin{array}{c}11 \\
3\end{array}$ & $\begin{array}{c}11 \\
4 \\
1\end{array}$ & $\begin{array}{c}12 \\
1 \\
1 \\
1\end{array}$ & $\begin{array}{l}\text { Satu ikan mati } \\
\text { bulan Feb. } 1995 \\
\text { One fish die on } \\
\text { Feb. } 1995\end{array}$ \\
\hline $\begin{array}{l}\text { Kematangan } \\
\text { Maturity }\end{array}$ & & 0 & 2 & 2 & 9 & 5 & 5 & 3 & \\
\hline 100 & $\begin{array}{c}\text { Neg } \\
\text { PV } \\
\text { SV } \\
\text { MV } \\
\text { LV } \\
+1 \\
+2 \\
+3 \\
\end{array}$ & 16 & $\begin{array}{c}13 \\
3\end{array}$ & $\begin{array}{c}11 \\
1 \\
2\end{array}$ & $\begin{array}{l}8 \\
2 \\
\\
1 \\
1 \\
1 \\
1 \\
1 \\
\end{array}$ & $\begin{array}{l}6 \\
3 \\
1\end{array}$ & $\begin{array}{l}9 \\
3 \\
\\
1 \\
1 \\
\\
1\end{array}$ & $\begin{array}{c}11 \\
3\end{array}$ & $\begin{array}{l}\text { Satu ikan mati } \\
\text { bulan Nov. } 1995 \\
\text { One fish die on } \\
\text { Nov. } 1995\end{array}$ \\
\hline $\begin{array}{l}\text { Kematangan } \\
\text { Maturity }\end{array}$ & & 0 & 3 & 5 & $7 *$ & $9 * \star *$ & 6 & $4^{*}$ & \\
\hline 150 & $\begin{array}{c}\text { Neg } \\
\text { PV } \\
\text { SV } \\
\text { MV } \\
\text { LV } \\
+1 \\
+2 \\
+3 \\
\end{array}$ & 16 & $\begin{array}{l}9 \\
2 \\
2\end{array}$ & $\begin{array}{l}7 \\
3 \\
1 \\
1 \\
1 \\
\\
\\
2\end{array}$ & $\begin{array}{c}10 \\
3 \\
1 \\
1\end{array}$ & $\begin{array}{l}7 \\
6 \\
1\end{array}$ & $\begin{array}{c}11 \\
3\end{array}$ & $\begin{array}{c}10 \\
4\end{array}$ & $\begin{array}{l}\text { Satu ikan mati } \\
\text { bulan Okt. } 1995 \\
\text { One fish die on } \\
\text { Oct. } 1995\end{array}$ \\
\hline $\begin{array}{l}\text { Kematangan } \\
\text { Maturity }\end{array}$ & & 0 & 7 & 8 & $5^{\star}$ & 8 & 4 & 5 & \\
\hline $\begin{array}{l}\text { Kontrol } \\
\text { Control }\end{array}$ & $\begin{array}{c}\text { Neg } \\
\text { PV } \\
\text { SV } \\
\text { MV } \\
\text { LV } \\
+1 \\
+2 \\
+3 \\
\end{array}$ & 8 & 1 & 7 & 7 & $\begin{array}{l}4 \\
3\end{array}$ & $\begin{array}{l}5 \\
2\end{array}$ & 6 & $\begin{array}{l}\text { Satu ikan mati } \\
\text { bulan Okt. } 1995 \\
\text { One fish die on } \\
\text { Oct. } 1995\end{array}$ \\
\hline $\begin{array}{l}\text { Kematangan } \\
\text { Maturity }\end{array}$ & & 0 & 1 & 0 & 0 & 3 & 2 & 1 & \\
\hline
\end{tabular}

Neg. : Negative

SV : Small Vit (egg diameter 250-400 $\mu \mathrm{m})$

$L V$ : Large Vit (egg diameter 600-750 $\mathrm{m}$ )

* : : One fish spawned

*** : Three fishes spawned
PV : Previtellogenetic (egg diameter 150-250 $\mu \mathrm{m}$ )

MV : Medium Vit (egg diameter 400-600 $\mu \mathrm{m}$ )

+1-+3: Amount of sperm 
sel telur pada induk betina sangat cepat, yaitu diketahui dalam waktu 1 bulan perubahan sel telur dari small vitellogenesis (diameter telur 250. $400 \mu \mathrm{m}$ ) menjadi medium vitellogenesis (diameter 400-600 $\mu \mathrm{m}$ ) dan bahkan large vitellogenesis (diameter telur $>600 \mu \mathrm{m}$ ). Pengaruh kecepatan perkembangan sel telur nampaknya disebabkan oleh implan vitamin $\mathrm{E}$ melalui otot punggung yang sangat berpengaruh langsung pada gonad.

Ditinjau dari analisis total kolesterol pada Tabel 2 terlihat bahwa pada perlakuan tanpa penambahan vitamin $\mathrm{E}$ (kontrol) maupun yang diimplan dengan vitamin $\mathrm{E}$ diketahui jumlah kolesterol yang terkandung pada serum darah menunjukkan angka yang meningkat. Hal tersebut disebabkan oleh penambahan kolesterol setiap bulan melalui implan, sehingga total kolesterol dalam plasma darah meningkat. Kolesterol penting digunakan dalam proses ovogenesis terutama pada sistem pembuatan pakan untuk induk (Kanazawa et al., 1988). Meningkatnya plasma kolesterol dalam darah diketahui dapat menurunkan kepadatan lipoprotein; rendah (Low Density Lipoprotein/LDL) dan sangat rendah
(Very Low Density Lipoprotein/VLDL). LDL cukup untuk transportasi kolesterol ke lapisan ektrahepatik langsung menuju ke LDL reseptor yang berada di permukaan sel (Chupukcharoen et al., 1985). Diketahui pula bahwa akumulasi kolesterol banyak ditemui di organ ovari udang bila dibandingkan pada organ lainnya (Kanazawa et al. 1988). Dari pendekatan penelitian pada kelinci yang kekurangan vitamin $\mathrm{E}$, tingkat akumulasi kolesterol terdapat pada otot dan plasma darah. Dari hasil pengamatan terhadap plasma darah kelinci maupun udang sangat nyata terlihat timbunan kolesterolnya. Kolesterol yang terdapat dalam plasma darah pada hewanhewan lainnya diketahui dapat mempengaruhi proses reproduksi. Kolesterol dalam plasma darah induk bandeng diketahui berkisar antara 159,23-271,37 $\mu \mathrm{g} / \mathrm{mL}$ pada ikan dewasa dan cenderung meningkat antara 340,83-365,81 $\mu \mathrm{g} /$ $\mathrm{mL}$ setelah diimplan dengan vitamin $\mathrm{E}$ yang diformulasikan dalam kolesterol (Tabel 2). Dengan meningkatnya kolesterol dalam darah diharapkan proses reproduksi induk bandeng dapat dipengaruhi.

Tabel 2. Pengamatan rata-rata total kolestrol dan vitamin E dalam serum darah ikan ( $\mu$ g/ikan). Table 2. Observation on total of mean cholesterol and vitamin E in blood serum of fish ( $\mu \mathrm{g} / \mathrm{fish}$ ).

\begin{tabular}{|c|c|c|c|c|}
\hline \multirow{2}{*}{$\begin{array}{l}\text { Perlakuan } \\
\text { Treatment } \\
\quad(\mu g)\end{array}$} & \multirow{2}{*}{$\begin{array}{l}\text { Analisis } \\
\text { Analysis } \\
(\mu \mathrm{g} / \mathrm{mL})\end{array}$} & \multicolumn{3}{|c|}{$\begin{array}{l}\text { Bulan } \\
\text { Month }\end{array}$} \\
\hline & & Sept. & Okt. (Oct.) & Nov. \\
\hline 50 & $\begin{array}{c}\text { T.C } \\
\text { Vit. E }\end{array}$ & $\begin{array}{l}271.37 \\
\quad 9.03(16)\end{array}$ & $\begin{array}{l}325.36 \\
2.68(2)\end{array}$ & $\begin{array}{l}340.83 \\
22.66(4)\end{array}$ \\
\hline 100 & $\begin{array}{c}\text { T.C } \\
\text { Vit. E }\end{array}$ & $\begin{array}{l}252.52 \\
\quad 9.43(16)\end{array}$ & $\begin{array}{l}337.62 \\
2.11(2)\end{array}$ & $\begin{array}{r}346.95 \\
0(0)\end{array}$ \\
\hline 150 & $\begin{array}{c}\text { T.C } \\
\text { Vit. E }\end{array}$ & $\begin{array}{l}159.23 \\
9.87(16)\end{array}$ & $\begin{array}{l}344.97 \\
1.68(1)\end{array}$ & $\begin{array}{r}362.65 \\
0(0)\end{array}$ \\
\hline $\begin{array}{l}\text { Kontrol } \\
\text { Control }\end{array}$ & $\begin{array}{c}\text { T.C } \\
\text { Vit. E }\end{array}$ & $\begin{array}{l}250.23 \\
9.25(8)\end{array}$ & $\begin{array}{l}355.98 \\
0(0)\end{array}$ & $\begin{array}{l}365.81 \\
0(0)\end{array}$ \\
\hline
\end{tabular}

TC: Jumlah kolesterol (Total cholesterol)

(): Jumlah ikan yang mempunyai kandungan vitamin E pada serum darah (Number of fish having vitamine $E$ in blood serum) 
Hasil pengamatan vitamin $\mathrm{E}$ pada induk yang diberi implan vitamin $\mathrm{E}$ dosis 50, 100 dan $150 \mu \mathrm{g}$ pada bulan pertama menunjukkan kadar vitamin $\mathrm{E}$ dalam serum darah berkisar antara 9.03-9.87 $\mu \mathrm{g} / \mathrm{mL}$, dengan kondisi gonad negatif. Setelah diimplan dengan dosis vitamin $\mathrm{E}$ berbeda, kadar vitamin $\mathrm{E}$ dalam serum darah menurun antara $1,68-2,68 \mu \mathrm{g} / \mathrm{ml}$, dan pada bulan berikutnya menurun antara 0-22.66 $\mu \mathrm{g} / \mathrm{mL}$. Menurunnya kadar vitamin $\mathrm{E}$ dalam serum darah adalah karena sebagian vitamin $\mathrm{E}$ yang ada diperlukan untuk pembentukan sel telur, sehingga sel telur dalam gonad mengalami perubahan dari previtellogenesis hingga large vitellogenesis. Nampaknya vitamin $\mathrm{E}$ dalam plasma darah berfungsi untuk mengontrol mobilisasi perkembangan oosit pada pematangan gonad induk betina. Hal ini nampak dari pengamatan kanulasi perkembang an gonad khususnya induk betina bandeng terutama yang diimplan dengan vitamin $\mathrm{E}$ dosis 100 dan $150 \mu \mathrm{g}$ (Tabel 1). Hal ini mungkin karena vitamin $\mathrm{E}$ yang berada dalam darah bersamasama dengan kolesterol banyak berperan dalam pembetukan ovari dalam gonad, dan selanjutnya akan berfungsi aktif dalam pembentukan sel telur. Hasil analisis vitamin E pada telur ikan bandeng membuktikan bahwa kandungan vitamin $\mathrm{E}$ dalam telur berada pada kisaran antara 28,58-103,6 $\mu \mathrm{g} / \mathrm{g}$ (Tabel 3). Nampaknya vitamin E yang diberikan dalam bentuk kristal sangat efektif digunakan untuk mempercepat pematang. an gonad. Perkembangan gonad memperlihatkan bahwa induk betina lebih cepat matang gonad bila dibandingkan dengan induk jantan.

Nilai indeks aktivitas kehidupan (SAI) pada larva hasil implantasi dosis vitamin E $100 \mu \mathrm{g}$ berkisar antara 0-5,46 dengan rata-rata 1,2 adalah lebih rendah bila dibandingkan dengan hasil larva yang diimplan dengan vitamin $\mathrm{E}$ dosis $150 \mu \mathrm{g}$ yaitu sebesar 6,79. Indeks aktivitas kehidupan larva erat kaitannya dengan kualitas telur yang dihasilkan. Makin tinggi nilai SAI merupakan indikator meningkatnya mutu telur, sehingga perlakuan dengan pemberian implan vitamin $\mathrm{E}$ dosis $150 \mu \mathrm{g}$ diduga mampu meningkatkan mutu larva yang dihasilkan.

Tabel 3. Pengamatan jumlah, kualitas telur, indeks aktivitas kehidupan dari larva bandeng dan kandungan vitamin $\mathrm{E}$ dalam telur

Table 3. Observation on number, quality of eggs, survival activity index of milkfish larvae and vitamine E content in eggs

\begin{tabular}{|c|c|c|c|c|c|c|c|c|}
\hline No & $\begin{array}{l}\text { Tgl. } \\
\text { Date }\end{array}$ & $\begin{array}{l}\text { Perlakuan } \\
\text { Treatment } \\
\quad(\mu \mathrm{g})\end{array}$ & $\begin{array}{c}\text { Wadah } \\
\text { Tank }\end{array}$ & $\begin{array}{l}\text { Jumlah } \\
\text { telur } \\
\text { Total } \\
\text { eggs } \\
\text { (x 000) }\end{array}$ & $\begin{array}{l}\text { Tingkat } \\
\text { pembuahan } \\
\text { Fertility } \\
(\%)\end{array}$ & $\begin{array}{l}\text { Tingkat } \\
\text { penetasan } \\
\begin{array}{c}\text { Hatching } \\
\text { rate }\end{array} \\
(\%)\end{array}$ & S.A.I & $\begin{array}{l}\text { Vit E } \\
(\mu \mathrm{g} / \mathrm{g})\end{array}$ \\
\hline 1 & $11 / 26 / 95$ & 150 & C3 & 187 & 30.48 & 83 & 6.79 & ND \\
\hline 2 & $11 / 28 / 95$ & 100 & $\mathrm{C} 2$ & 560 & 87.14 & 97 & 5.46 & 28.58 \\
\hline 3 & $12 / 02 / 95$ & 100 & $\mathrm{C} 2$ & 367 & 0 & 0 & 0 & ND \\
\hline 4 & $12 / 18 / 95$ & 100 & $\mathrm{C} 2$ & 320 & 91.56 & 5 & 0 & 103.8 \\
\hline 5 & $12 / 19 / 95$ & 100 & $\mathrm{C} 2$ & 396 & 94.69 & 8 & 0.54 & 49.41 \\
\hline 6 & $02 / 01 / 96$ & 100 & $\mathrm{C} 2$ & 265 & 0 & 40 & 0 & ND \\
\hline
\end{tabular}

S.A.I : Indeks akt1vitas kehidupan (Survival Activity Index)

ND : tidak ada data (No data available) 
Hasil pengamatan pembuahan telur bandeng pada bulan November diketahui sebesar $87,14 \%$ dari telur sebanyak 560.000 butir, dan daya tetas sebesar 97,0\%, sedangkan pada bulan Desember tingkat pembuahan sebesar 0; 91,56 dan 94,69\% dan daya tetasnya $0 ; 5$ dan $84 \%$ dari 3 kali bertelur. Pada bulan Februari induk bandeng dengan implan vitamin $\mathrm{E}$ dosis $100 \mu \mathrm{g} / \mathrm{ekor}$ bertelur sebanyak 265.000 butir namun tidak dibuahi. Pada bulan November induk memijah satu kali dengan jumlah telur 187.000 butir dan tingkat pembuahannya sangat rendah, yaitu $37,48 \%$, namun daya tetas cukup tinggi mencapai $83 \%$ (Tabel 3). Rendahnya tingkat pembuahan mungkin disebabkan oleh ketidakserasian perkembangan sel telur dan sperma, yaitu sel telur induk betina diketahui $>600 \mu \mathrm{m}$ dan jantan masih positip 2, dengan demikian jumlah dan kualitas sperma induk jantan tidak mampu untuk membuahi telur. Sinkronisasi perkembangan gonad jantan dan betina secara fisiologis berbeda, yaitu induk betina dapat bertelur secara partial 2-3 kali setiap bulan karena pengaruh hormonal (Prijono et al., 1993) sedangkan pada yang jantan, gonad berkembang normal setiap bulan sekali. Pengaruh tersebut dapat dilihat dari hasil pemijahan bulanan dengan variasi pembuahan telur dan penetasan hingga $94.69 \%$ dan $97 \%$.

Dari frekuensi pemijahan diketahui induk bandeng yang diimplan dengan vitamin $\mathrm{E}$ dosis $100 \mu \mathrm{g}$ dapat memijah sebanyak 5 kali dengan produksi sebanyak 1.908 .000 butir dengan kisaran antara 265.000-560.000 butir telur. Frekuensi pemijahan induk bandeng dengan perlakuan implan vitamin $\mathrm{E}$ dengan dosis $100 \mu \mathrm{g}$ cenderung meningkat. Hal ini kemungkinan disebabkan karena pengaruh pemberian vitamin $\mathrm{E}$ untuk merangsang perkembangan gonad yang bertepatan dengan musim pemijahan alami. Sedangkan induk bandeng yang diimplan dengan vitamin $\mathrm{E}$ dosis $150 \mu \mathrm{g}$ mampu memijah satu kali saja dengan jumlah telur 187.000 butir telur. Pada induk yang dimplan dengan vitamin $\mathrm{E}$ dosis $50 \mu \mathrm{g}$ dan yang tanpa vitamin $\mathrm{E}$ tidak menunjukkan tanda-tanda untuk memijah.

Parameter kualitas air yang diamati selama percobaan meliputi salinitas, suhu, oksigen terlarut, nitrit, nitrat, phosphat dan $\mathrm{pH}$ disajikan pada Tabel 4.

Dari hasil pengamatan terhadap kualitas air pemeliharaan induk diketahui bahwa kualitas air masih pada kisaran yang layak untuk kehidupan ikan. Menurut Prijono (1994) kisaran yang diperlukan adalah suhu antara $29,5-31,0^{\circ} \mathrm{C}$; salinitas antara 29,5-32,0 ppt; oksigen terlarut antara 4,0-6,5 ppm; nitrit antara 0,05-0,09 ppm; nitrat antara $0,01-0,06 \mathrm{ppm}$; fosfat antara $0,01-0,09$ ppm; dan $\mathrm{pH}$ antara 8,0-8,4.

Tabel 4. Kisaran parameter kualitas air selama percobaan.

Table 4. Range of water quality parameters observed during the experiment.

\begin{tabular}{llc}
\multicolumn{1}{c}{$\begin{array}{c}\text { Peubah } \\
\text { Variable }\end{array}$} & & $\begin{array}{c}\text { Kisaran } \\
\text { Range }\end{array}$ \\
\hline Salinitas (salinity) & ppt & $34.00-35.00$ \\
Suhu (temperature) & ${ }^{\circ} \mathrm{C}$ & $27.20-30.50$ \\
Oksigen terlarut (DO) & $\mathrm{ppm}$ & $4.82-8.27$ \\
Nitrit (nitrite) & $\mathrm{ppm}$ & $0.005-0.023$ \\
Nitrat (nitrate) & $\mathrm{ppm}$ & $0.013-0.063$ \\
Fosfat (phosphate) & $\mathrm{ppm}$ & $0.057-0.110$ \\
pH & & $8.29-8.47$ \\
\hline
\end{tabular}




\section{KESIMPULAN}

Implan vitamin $\mathrm{E}$ dengan dosis $100 \mu \mathrm{g}$ mem. berikan hasil yang terbaik, yaitu dapat mempercepat pematangan gonad ikan bandeng dan pemijahannya hingga 5 kali dengan tingkat pembuahan serta penetasan telur masing-masing $94,69 \%$ dan $97 \%$ dan kandungan kolesterol total tertinggi sebesar $346,95 \mu \mathrm{g} / \mathrm{ml}$.

\section{UCAPAN TERIMA KASIH}

Terima kasih kami sampaikan kepada staf Teknisi Litkayasa pembenihan bandeng a.l. Sdr Oka Suarjana, Agus Supriyatna, Made Suparya, Dedi Rohaniawan, Ni Putu Ari Arsini dan Ayu Kenak serta pekarya lainnya. Terima kasih pula disampaikan pada peneliti dan teknisi lainnya yang telah banyak membantu dalam pelaksanaan penelitian tersebut.

\section{DAFTAR PUSTAKA}

Bieri, J.G.; Tolliver, T.J and Catignani G.L. 1979. Simultaneous determination of $\alpha$ tocopherol and retinol in plasma of red cells by HPLC. American Journal Clinic Nutrition 32: 2143.

Chupukcharoen, N.; P. Komaratat and P. Wilairat. 1985. Effect of vitamin E deficiency on the distribution of cholesterol in plasma lipoprotein and the activity of cholesterol $7 \alpha$-hydroxylase in rabbit liver. Journal Nutrition 115: 468-472.

Cowey, C.B.; J.W. Adron and A. Youngson. 1983. The vitamin $\mathrm{E}$ requirement of rainbow trout (Salmo gairdneri) given diets containing polyunsaturated fatty acids derived from fish oil. Aquaculture 30: 85-93.

Crim, L.W. 1985. Methods for acute and chronic hormone administration in fish. Reproduction and culture of Milkfish. Proceedings for a workshop held at Tungkang Marine Laboratory, Taiwan p: 113.

Halver,J.E. 1985. Recent advances in vitamin nutrition and metabolism in fish. Nutrition and feeding in fish. Edited by C.B Cowey., A.M. Mackie and J.G. Bell. Academic Press London p: 415-429.

Kanazawa, A.; L. Chim and A. Laubier. 1988. Tissue uptake of radioactive cholesterol in the prawn
Penaeus japonicus Bate during induced ovarian maturation. Aquatic Living Resourses 1: 85-91.

Lee, C.S.; S.C. Tamaru.; J.J. Banno.; C.D Kelley.; A. Bocek, and J.E. Wyban. 1986. Induced natural and spawning of milkfish Chanos chanos Forsskal by hormon implantation. Aquaculture 52: 199-205.

Marte, C.L.; F.C. Lacanilao and J.V. Juario. 1985. Complantion of the life cycle of milkfish Chanos chanos (Forsskal) captivity. Paper presented during the second International milkfish Aquaculture Conference, Iloilo, Philippines.

Mushiake, K. and S. Sekiya. 1993. A trial of evaluation of activity in striped jack, Pseudocaranx dentex larvae. Suisanzoshoku Japan, Aquaculture Society. Kochi Japan 41 (2).

Prijono, A.; G. Sumiarsa dan Z.I. Azwar. 1990. Implantasi hormon LHRH-a dan atau $17 \propto$ MT untuk pematangan gonad induk bandeng. J. Penel. Budidaya Pantai 6 (2): 20-23.

Prijono, A.; G. Sumiarsa, dan Z. I. Azwar. 1993. Uji coba implantasi kristal hormon $17 \alpha$ methyltetos. terone untuk pemijahan induk bandeng, Chanoschanos Forsskal. J. Penelitian Budidaya Pantai, 9 (1): $37-42$.

Prijono, A. 1994. Pengaruh penambahan vitamin E dalam pakan untuk pematangan gonad induk bandeng Chanos chanos. J. Penelitian Budidaya Pantai 10 (3): 1-8.

Pozo, R.; J. Lavety and R. Malcom. 1988. The role of dietary $\alpha$ tocopherol (vitamin $E$ ) in stabilising the canthaxanthin and lipid of rainbow trout muscle. Aquaculture 73: 165- 175.

Watanabe, T.; Takeuchi, T.; Matsui, M.; Ogino, C. and Kawabata. 1977. Effect of $\alpha$-tocopherol deficiency on carp. VII. The relationship between dietary levels of linoleate and $\alpha$-tocopherol requirement. Bull. Jpn. Soc.Sci. Fish 43: 935-946.

Watanabe, T.; A. Itoh.; A.F. Murakami.; Y. Tsukhasima.; C. Kitajima and S. Fujita. 1984. Effects of nutritional quality of diets given to broodstock on the verge of spawning on reproduction of red sea bream. Bull. Japan SAoc. Scient, Fish. 50: 10231028.

Watanabe, T. 1985. Importance of the study of broodstock nutrition for further development of aquaculture. Nutrition and feeding in fish. Edited by C.B Cowey, A.M. Mackie and I.B. Bell. Academic Press London 395-414. 